(C) 2014

Іващенко О. Д. , кандидат хімічних наук

Вищий навчальний заклад Укоопспілки «Полтавський університет економіки і торгівлі»

Момот Ю. В., кандидат педагогічних наук

Вищий навчальний заклад Укоопспілки «Полтавський університет економіки і торгівлі»

\title{
ІДЕНТИФІКАЦІЯ НАРКОТИЧНО ДІЮЧИХ РЕЧОВИН У КОСТРІ КОНОПЛЯНІЙ
}

\section{Рецензент - кандидат хімічних наук В. Ю. Крикунова}

\begin{abstract}
Стаття присвячена важливому питанню: дослідження відходів конопель сучасного сорту ЮСО-31 на вміст наркотично діючих речовин. Визначення канабіноїдів у здерев 'янілих частинах стеблин рослин коноплі (кострі) здійснювалося різними методами. Мікроскопічне морфологічне визначення рослинного об 'єкту проводилося з метою доведення належності його до конопель. Представлені також результати ідентифікації тетрагідроканабінолу за допомогою якісних хімічних реакцій та кількісного аналізу методом газової хроматографії.
\end{abstract}

Ключові слова: коноплі, тетрагідроканабінол, костра конопляна, канабіноїди, газова хроматографія з мас-селективним детектуванням.

Постановка проблеми. В України про коноплі як про наркотик заговорили після перебудови СРСР. Наркотична активність конопель визначається наявністю канабіноїдних сполук, основними 3 яких є канабідіол (КБД), тетрагідроканабінол (ТГК) і його ізомери, канабінол (КБН). Найбільш висока токсичність характерна для ТГК і його ізомерів. Канадські дослідники виділяють 426 компонентів канабіноїдів, 3 яких 62 представляють різні видозміни ТГК. Усі вони близькі між собою і належать до однієї групи природних фенолів.

У зв'язку з цим перед українськими ученимселекціонерам - із метою попередження розвитку наркоманії - було поставлено завдання вивести сорти посівних конопель, які б не мали наркотичного ефекту. Українські безнаркотичні сорти конопель зареєстровані й вирощуються як звичайна польова культура в країнах $Є C$, Канаді, Китайській Народній Республіці, Російській Федерації. Адже згідно із законодавством перерахованих країн, коноплі, у яких вміст тетрагідроканабінолу не перевищує $0,2 \%$, не відносять до культур, що містять наркотичні речовини, i культивуються без усіляких обмежень [2].

Однак в Україні висунуті необгрунтовані ліцензійні умови платної охорони посівів конопель підрозділами МВС України [1], чого не передбачено законодавством жодної країни світу, та вимоги щодо знищення рослинних залишків (подрібнення, розкидання по полю), що абсолютно неприйнятно для конопель, стебла якої $\epsilon$ цінним джерелом лубоволоконної сировини. У результаті наведені вимоги Ліцензійних умов зумовили втрату у господарств зацікавленості у вирощуванні конопель, що призвело до різкого скорочення посівних площ культури і поступового занепаду галузі: $з$ 7,7 тис. гектарів у 1991 році площа під коноплями в 2008 році скоротилася до 810 га [7].

Безумовно, Україна втрачає свою доступну сировинну базу, що грунтується на вирощуванні й переробці конопель - традиційної для нашої країни технічної культури, а в економічному плані - незалежність у виробництві товарів промислового використання та народного споживання з натурального волокна.

Аналіз основних досліджень і публікацій, у яких започатковано розв'язання проблеми. Ще 3 70-х років вчені-селекціонери Інституту луб'яних культур працювали над тим, аби рівень тетрагідроканабінолу (основної наркотичної речовини коноплі) у нових сортах не перевищував $0,1 \%$. Вирощувану коноплю розрізняли за вмістом канабіноїдів, але сортів із повною їх відсутністю не було. Більше того, чим менше містилося у зразку цієї речовини, тим меншу господарську цінність вона представляла [5].

Приблизно за двадцять років роботи вчені, зокрема В. Вировець, Л. Горшкова, Г. Сенченко та інші, створили безнаркотичні та високоврожайні сорти, районовані для Полтавської, Черкаської, Сумської областей. Глухівські сорти цінності як наркосировина не мали. Вміст психоактивного компонента - тетрагідроканабінолу - у вирощених інститутом рослинах був у 50 разів меншим визначеного законом максимуму $(0,15 \%)$ [8].

Створенню безнаркотичних конопель і дослідженню особливостей накопичення канабіноїдних речовин конопель присвячені роботи багатьох вчених Інституту луб'яних культур, таких як М. Д. Мигаль, В. М. Рухленко, І. М. Лайко, І. Л. Шульга, С. В. Міщенко та інші [7; 8]. 


\section{СІЛЬСЬКЕ ГОСПОДАРСТВО. РОСЛИННИЦТВО}

Метою дослідження $є$ проведення ідентифікації канабіноїдів у кострі конопляній, визначення оптимальних умов кількісного аналізу канабіноїдів методом газової хроматографії з масселективним детектуванням. Для досягнення цієї мети були поставлені наступні завдання:

- вивчити вміст основних канабіноїдів у кострі конопляній;

- удосконалити якісні хімічні реакції виявлення канабіноїдів;

- провести експертизу костри конопляної на вміст нарктичнодіючих речовин.

Об'сктом дослідження слугував продукт переробки відходів конопель - костра, яка виготовляється 3 технічних конопель сорту ЮСО-31 посіву ТОФ «АГРО-ХАНФ».

Методи досліджень. Для ідентифікації наркотичнодіючих речовин були використані наступні методи:

- мікроскопічний опис анатомо-морфологічних ознак конопель;

- якісні хімічні реакції виявлення канабіноїдів iз реагентом тривким синім Б, із реагентом К та реактивом Паулі, які вказують на можливу наявність канабіноїдів;

- кількісне визначення канабіноїдних речовин методом газової хроматографії з мас-селективним детектуванням.

Результати дослідження. Дослідження проводилося у 2012 році на базі кафедри хімії ВНЗУ «Полтавський університет економіки і торгівлі» (морфологічне дослідження та якісні хімічні реакції) та лабораторії спеціальних видів експертизи відділу експертизи наркотичних засобів, психотропних речовин, їх аналогів та прекурсорів ДНДЕКЦ при МВС України в Полтавській області (кількісне визначення методом газової хроматографіi).

Проведення ідентифікації ми розпочинали 3 морфологічного дослідження. Мета морфологічного дослідження - встановлення виду рослини [6]. Даний вид дослідження проводили за допомогою мікроскопа.

Препарати для мікроскопічного дослідження готували із сировини (верхівки рослин), попередньо освітленої в розчині лугу.

Для цього шматочки досліджуваної речовини кип'ятили у пробірці з освітлюючою рідиною 1-2 хвилини, після чого рідину зливали, а речовину промивали й залишали у воді.

Далі шматочки речовини брали препарувальною голкою і переносили на предметне скельце. Провівши мікроскопічне дослідження, зробили висновок, що дане волокно досить схоже на лляне, хоча, на відміну від лляного волокна, в ньому відсутні колінні уступи.

Тому можна стверджувати, що дане волокно волокно рослини конопель.

Наступним етапом ідентифікації були якісні хімічні реакції виявлення канабіноїдів.

Особливістю даних реакцій $\epsilon$ те, що вони дають підставу стверджувати лише про можливу наявність канабіноїдів у досліджуваному об'єкті, а тому мають бути обов'язково підтверджені іншими фізико-хімічними методами.

Було проведено три якісні реакції: з реагентом тривким синім Б, із реагентом К та реактивом Паулі. Результати даних якісних хімічних реакцій наведені в таблиці [3; 4].

Для визначення компонентного складу досліджуваного зразка застосовували метод газової хроматографії з мас-селективним детектуванням.

Особливістю цього методу є отримання масспектрів - сортування заряджених частинок по відношенню їх маси до заряду.

Дані мас-спектри є своєрідними «відбитками пальців» для кожного матеріалу та речовини $[4 ; 6]$.

\section{Реакція досліджуваного об'єкта на реактиви}

\begin{tabular}{|c|c|c|c|}
\hline $\begin{array}{c}\text { Вид } \\
\text { реактиву }\end{array}$ & $\begin{array}{c}\text { За наявності канабіноїдів } \\
\text { поява: }\end{array}$ & Спостереження & Висновок \\
\hline $\begin{array}{c}\text { Тривкий } \\
\text { синій Б }\end{array}$ & $\begin{array}{c}\text { пурпурово-червоне забарвлен- } \\
\text { ня в хлороформному шарі }\end{array}$ & $\begin{array}{c}\text { хлороформний шар } \\
\text { не змінив забарвлення }\end{array}$ & $\begin{array}{c}\text { у досліджуваному } \\
\text { об'єкті канабіноїди } \\
\text { відсутні }\end{array}$ \\
\hline Реагент К & $\begin{array}{c}\text { фіолетове забарвлення } \\
\text { в хлороформному шарі }\end{array}$ & $\begin{array}{c}\text { хлороформний шар } \\
\text { не змінив забарвлення }\end{array}$ & $\begin{array}{c}\text { у досліджуваному } \\
\text { об'єкті канабіноїди } \\
\text { відсутні }\end{array}$ \\
\hline $\begin{array}{c}\text { Реактив } \\
\text { Паулі }\end{array}$ & $\begin{array}{c}\text { коричнево-червоне } \\
\text { забарвлення }\end{array}$ & $\begin{array}{c}\text { хлороформний шар } \\
\text { не змінив забарвлення }\end{array}$ & $\begin{array}{c}\text { у досліджуваному } \\
\text { об'єкті канабіноїди } \\
\text { відсутні }\end{array}$ \\
\hline
\end{tabular}




\section{СІЛЬСЬКЕ ГОСПОДАРСТВО. РОСЛИННИЦТВО}

Для кількісного аналізу брали точну наважку усередненої проби масою 0,5 г костри конопляної, яку екстрагували 5 мл етилацетату, що містить 0,5 мг/мл n-докозану, при кімнатній температурі протягом 30 хвилин (струшуючи колбу).

Одержаний розчин фільтрували, переносили до віали та аналізували на хромато-масспектрометрі за наступних умов: $\mathrm{N}$;

- прилад - GC/MC Agilent Technologies 6890/5975

- капілярна колонка - HP 19091S-433 (HP5MS), довжина - 30 м, діаметр - 0,32 мм, фаза 0,25 мкм; 20:1;

- введення проби - автоінжектор 7683, Split

- газ-носій - гелій, постійний потік - 1,5 мл/хв.;

- температура випарника $-\mathrm{T}=250{ }^{\circ} \mathrm{C}$;

- піч $-\mathrm{T}_{\text {поч }}=100{ }^{\circ} \mathrm{C}$, тримати 2 хв., нагрівання $-15^{0} \mathrm{C} / \mathrm{xв}, \mathrm{T}_{\text {кінц }}=280{ }^{\circ} \mathrm{C}$, тримати 11 хв.;

- детектор - мас-селективний, температура інтерфейса $\mathrm{T}=280{ }^{\circ} \mathrm{C}$, йонізація - електронним ударом;

- енергія йонізації - $70 \mathrm{eB}$, температура йонного джерела $\mathrm{T}=230{ }^{\circ} \mathrm{C}$; температура квадруполя $\mathrm{T}=150{ }^{\circ} \mathrm{C}$

- проба - 1 мкл.

У результаті газохроматографічного аналізу у досліджуваному об'єкті (верхівках рослин конопель) виявлено тетрагідроканабінол.

Розрахунок відсоткового вмісту тетрагідроканабінолу проводили методом зовнішнього стандарту за формулою:

\section{БІБЛІОГРАФІЯ:}

1. Антинаркотичне законодавство: характеристика закону України «Про обіг в Україні наркотичних засобів, психотропних речовин, їх аналогів і прекурсорів» // Юридичний вісник України. - 1997. - № 21. - С. 18-31.

2. Бабаян Э. А. Правовые аспекты оборота наркотических, психотропных, сильнодействующих, ядовитых веществ и их прекурсоров / Э. А. Бабаян. - М. : Медицина, 2003. -302 с.

3. Дослідження наркотиків, поширених на території України: метод. рекомендації / С. О. Шимановський, В. Т. Машкін, О.П. Замошець, І. В. Семенова. - К. : ДНДЕКЦ, 1997. - 92 с.

4. Еремин С. К. Анализ наркотических средств / С. К. Еремин, Б. Н. Изотов, Н. В. Веселовская. М. : Мысль, 1993. - 138 с.

5. Кабанещь B. Ненаркотичні посівні коноплі -

$$
\mathrm{X}(\%)=\frac{C_{\text {тгк }} \times V_{p}}{M} \times 100 \%, \text { де: }
$$

$X$ - відсотковий вміст тетрагідроканабінолу;

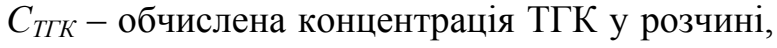
мг/мл;

$V p$ - об'єм розчинника, мл;

$M$ - маса наважки досліджуваного об'єкта, мг.

Програмою обробки даних Chemstation встановлено, що середній відсотковий вміст тетрагідроканабінолу в досліджуваній кострі конопель становить $0,002 \%$ мас.

Такий результат свідчить про мінімальний вміст тетрагідроканабінолу і неможливість використання костри конопляної в якості наркотичного засобу. Це, на нашу думку, є вагомим аргументом щодо використання костри як цінної сировини лубоволоконної галузі з метою організації безвідходного виробництва.

\section{Висновки:}

1. Проведена ідентифікація наркотично діючих речовин у кострі конопляній за допомогою якісних хімічних реакцій та газової хроматографiї $з$ мас-селективним детектуванням.

2. Морфологічне дослідження показало, що досліджуваний зразок відноситься до рослин виду конопель.

3. Якісні хімічні реакції з реагентом тривким синім Б, реагентом К та реактивом Паулі вказали на можливу відсутність канабіноїдів.

4. Методом газової хроматографії 3 масселективним детектуванням було встановлено вміст тетрагідроканабінолу у досліджуваному об’єкті: $0,002 \%$.

культура невичерпних можливостей / В. Кабанець, В. Вировець, І. Лайко // Агробізнес сьогодні. - 2012. - № 11. - С. 30.

6. Лазурьевский В. Г. Каннабиноиды. Наркотические вещества конопли / В. Г. Лазурьевский, Л. А. Николаева. - Кишинев : Штиинца, 1972. $68 \mathrm{c}$.

7. Мигаль М. Д., Шульга І. Л. Відмінності сортів конопель за вмістом канабіноїдів // Режим доступу: http://archive.nbuv.gov.ua/portal/Chem_Biol/znpilk/ 2011_1/7_Migal_.pdf

8. Наркотическая активность конопли (Cannabis sativa L.) и перспективы селекции на снижение содержания каннабиноидов / Г. И. Сенченко, Л. М. Горшкова, В. Г. Вировец [и др.] // С.-х. биология. - 1991. - № 1. - С. 35-49. 